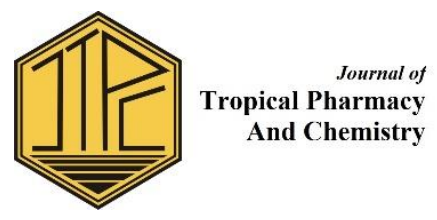

\title{
ANTIOXIDANT ACTIVITY OF ETHANOL EXTRACT COMBINATIONS OF JERUK PURUT LEAF (CITRUS HYSTRIX DC.) AND JATI BELANDA LEAF (GUAZUMA ULMIFOLIA L.)
}

\section{Arina Nisyya Nadhira*, Safira Maharani, Fransisda Aulia Zatsyia, Ika Trisharyanti, Dian Kusumowati}

Faculty of Pharmacy University of Muhammadiyah Surakarta

*Corresponding author: k100150149@student.ums.ac.id

\begin{abstract}
Ethanol extracts of Guazuma ulmifolia L. and Citrus hystrix Dc., have a strong antioxidant activity. The purpose of this research is to determine the antioxidant activity of ethanol extracts combination of Guazuma ulmifolia L. (jati belanda leaf) and Citrus hystrix Dc (jeruk purut leaf). Determination of antioxidant activity was done by DPPH method (1,1-diphenyl2picrylhydrazil) using UV-Vis spectrophotometer with maximum wavelength $516.5 \mathrm{~nm}$. The antioxidant activity of jeruk purut leaf is smaller than jati belanda leaf ( $\mathrm{IC}_{50} 48.70 \mu \mathrm{g} / \mathrm{mL}$ for jeruk purut leaf, $\mathrm{IC}_{50} 35.92 \mu \mathrm{g} / \mathrm{mL}$ for jati belanda leaf). Antioxidant activity of the two extracts combination was lower than the antioxidants of each extract (without combination). The low antioxidant activity of both extract combination due to the antagonist activity as the interaction of the content of each extract so that the extract combination showing a weaker antioxidant activity. At the concentration of each different comparison of each extract combination volume shown no difference with P-value > 0.05 (P-value: 0.99).
\end{abstract}

Keywords: Antioxidant, DPPH, Combination, Jeruk purut leaf, Jati belanda leaf

Submitted on: 10 July $2018 \quad$ Accepted on: 07 November 2018

DOI: https://doi.org/10.25026/jtpc.v4i4.175

\section{INTRODUCTION}

Free radicals are relatively unstable molecules with the outermost orbits of atoms that have one or more unpaired electrons [1]. Free radicals are one of the factors causing DNA damage other than virus. Cell division can be disrupted because of the breaking of DNA chains that cannot be repaired by the DNA repair system until it becomes a cancer [2].
Antioxidants are automatically produced by our body to prevent the free radicals spread through the body [3]. Antioxidant is a compound that have an important role in maintaining health because it can capture free radical molecules thereby inhibiting oxidative reactions in the body which cause some various diseases [4]. The body must obtain sufficient amount of antioxidants. Antioxidants can decrease their activity 
when excessive free radicals are forming so that our body needs an external antioxidant intake [5]. Natural antioxidants are obtained from classes of phenol derivatives such as flavonoids, hydroxamic acid derivatives, coumarins, tocopherols and organic acids which is present in plants [3].

Jati belanda is one of Indonesia's tropical plants that are often used to support the health of the human body [6]. Jati belanda leaf have antioxidant effects and phytochemical screening shows that it contains flavonoid compounds [7]. Jeruk purut leaf has exogenous antioxidant effect that can be used as an alternative to inhibiting the aging process (antiaging) because it contains citronellal, a powerful antioxidant. Phytochemical screening shows the jeruk purut leaf contain phenol, flavonoids, and terpenoids [8]. This study aims to determine the antioxidant activity of the combination of both plants because of the high antioxidant activity.

\section{MATERIALS AND METHODS}

UV-Vis spectrophotometer (UV Mini SHIMADZU), analytical balance, rotary evaporator, sonicator, Buchner funnel, micropipette (Socorex), cuvette, and glassware (pyrex).

\section{Plant Materials}

Ethanol extract of Citrus hyxtrix Dc. dan Guazuma ulmifolia L., ethanol 96\%, DPPH (1,1-diphenyl2picrylhydrazil), ethanol pro analysis (ethanol p.a), and aquabidestillata.

\section{Sample Extraction and Preparation}

The extraction of both samples was done by maceration. 50 grams of Jeruk purut leaf simplicia and 200 grams of jati belanda leaf were soaked with $96 \%$ ethanol (1:10) and stored in a glass container, tightly closed, left for 3 days, protected from light to avoid oxidation or evaporation, and stirred it occasionally.
After 3 days, the maserate was filtered with a Buchner funnel and remaserated the dregs with the same amount of solvent. Maserate is evaporated with a rotary evaporator and waterbath until it becomes a viscous extract.

Sample preparation for the DPPH assay was made from a total of $100 \mathrm{mg}$ from each extract was dissolved with 10 $\mathrm{mL}$ of ethanol p.a and synthesized to ensure the homogeneity of the solution.

\section{Antioxidant Assay}

Antioxidant assay was done by DPPH method. The DPPH solution was prepared from $15.77 \mathrm{mg}$ of DPPH powder dissolved with $100 \mathrm{~mL}$ ethanol p.a. The combination of extracts with a certain ratio was added with $1 \mathrm{~mL}$ of DPPH solution and ethanol p.a boundary marker of $5.0 \mathrm{~mL}$ flask. Incubation of the solution for 30 minutes and avoid it from the lights, read the absorbance of each ratio with UV-Vis spectrophotometer at maximum wavelength $516.5 \mathrm{~nm}$. The blank solution was ethanol p.a and the DPPH control consist of $1 \mathrm{~mL}$ DPPH solution added with ethanol p.a up to $5 \mathrm{~mL}$ boundary marker on the flask. Sample control of each combination of $1 \mathrm{~mL}$ and added ethanol p.a to the $5 \mathrm{~mL}$ boundary marker on the flask. Table 1 shows the certain ratio of extract combination.

The antioxidant activity determined with the inhibitory concentration $\left(\mathrm{IC}_{50}\right)$ and $\%$ antiradical from the extracts. Vitamin $\mathrm{E}$ used as the standard of high antioxidant activity. $\mathrm{IC}_{50}$ of vitamin $\mathrm{E}$ is $12.59 \mu \mathrm{g} / \mathrm{mL}$.

\section{Statistical Analysis}

Parameter used to find out the antioxidant activity of the extract combination was \% antiradical. The formula to calculate $\%$ antiradical is as follows.

$$
\% \text { antiradicd }=\frac{D P P H \text { absorbance }- \text { Sampleabsorbance }}{\text { DPPH absorbance }} \times 100 \%
$$


Another parameter to find out the antioxidant activity of the sole extract of jeruk purut leaf and jati belanda leaf was $\mathrm{IC}_{50}$ value. $\mathrm{IC}_{50}$ value was calculated by linear regression of the $\%$ antiradical of sole extract. The result obtained from the experiments analyzed using anova test.

\section{RESULT AND DISCUSSION}

Extract rendemen was $5.42 \%$ (jati belanda leaf extract) and $12.44 \%$ (jeruk purut leaf extract) and its calculated from the extract mass divided by simplicia mass.

The method used to test the antioxidant activity of ethanol extract combination of jeruk purut leaf and jati belanda leaf is DPPH method (2,2diphenyl-1-picrylhydrazyl). The principle of the DPPH method is by reacting the sample with DPPH reagent to see the inhibitory ability of the sample to DPPH as a radical compound. The parameters used to determine the antioxidant activity of the sample are \% antiradical and $\mathrm{IC}_{50}$ values. The results obtained in the study are presented as follows. The results obtained in the study are presented at table 1 and table 2 .

From the result obtained, the greater concentration of extracts result in the greater activity of antioxidants. $\mathrm{IC}_{50}$ of jati belanda leaf extract is smaller than the extract of jeruk purut leaf, where the results indicate that the antioxidant activity of jati belanda leaf extract is higher than the jeruk purut leaf extract. Smaller value of $\mathrm{IC}_{50}$ means greater effect of antioxidant to resist the DPPH activity as a free radical [9]. $\mathrm{IC}_{50}$ calculation results also prove that in the combination of the two extracts, which has contributed to the high antioxidant activity is jati belanda leaf extract which has the ability to inhibit DPPH radical activity higher. In addition, there were a compound as an antagonist to the combination result in lowering the antioxidant activity of the combination or lowering stability of the antioxidant. Stability of the antioxidant can be affected by temperature, changes of $\mathrm{pH}$, light, oxygen, and metal ions [10].

Table 1. \% Antiradical from certain ratio of extract combination

\begin{tabular}{ccc}
\hline $\begin{array}{c}\text { Volume of Jeruk purut Leaf } \\
\text { Extract (Concentration) }\end{array}$ & $\begin{array}{c}\text { Volume of Jati belanda Leaf } \\
\text { Extract (Concentration) }\end{array}$ & \%Antiradical $\pm \mathrm{SD}$ \\
\hline $120 \mu \mathrm{L}(0.024 \%)$ & $0(0 \%)$ & $64.75 \% \pm 0.15$ \\
$40 \mu \mathrm{L}(0.008 \%)$ & $80 \mu \mathrm{L}(0.016 \%)$ & $54.78 \% \pm 0.09$ \\
$60 \mu \mathrm{L}(0.012 \%)$ & $60 \mu \mathrm{L}(0.012 \%)$ & $50.98 \% \pm 0.17$ \\
$80 \mu \mathrm{L}(0.016 \%)$ & $40 \mu \mathrm{L}(0.008 \%)$ & $44.96 \% \pm 0.29$ \\
$0 \mu \mathrm{L}(0 \%)$ & $120 \mu \mathrm{L}(0.024 \%)$ & $78.76 \% \pm 0.12$ \\
\hline
\end{tabular}

Table $2 . \mathrm{IC}_{50}$ value of the sole extract

\begin{tabular}{ccccc}
\hline \multirow{2}{*}{ Concentrations } & \multicolumn{2}{c}{ Jeruk purut leaf extract } & \multicolumn{2}{c}{ Jati belanda leaf extract } \\
\cline { 2 - 5 } & \% Antiradical $\pm \mathrm{SD}$ & $\mathrm{IC}_{50}$ & \% Antiradical $\pm \mathrm{SD}$ & $\mathrm{IC}_{50}$ \\
\hline $1250 \mu \mathrm{g} / \mathrm{mL}$ & $84.69 \% \pm 0.10$ & $92.262 \% \pm 0.00$ & \\
$625 \mu \mathrm{g} / \mathrm{mL}$ & $78.42 \% \pm 0.10$ & $88.318 \% \pm 0.10$ & \\
$312.5 \mu \mathrm{g} / \mathrm{mL}$ & $48.35 \% \pm 0.00$ & $48.70 \mu \mathrm{g} / \mathrm{mL}$ & $67.188 \% \pm 0.10$ & $35.92 \mu \mathrm{g} / \mathrm{mL}$ \\
$156.25 \mu \mathrm{g} / \mathrm{mL}$ & $26.852 \% \pm 0.10$ & $28.646 \% \pm 0.10$ & \\
$78.125 \mu \mathrm{g} / \mathrm{mL}$ & $10.897 \% \pm 0.10$ & $12.798 \% \pm 0.00$ & \\
\hline Linear & $\mathrm{r}=0.8925$ & $\mathrm{r}=0.838$ \\
Regression: & $\mathrm{y}=598.112 \mathrm{x}+20.871$ & $\mathrm{y}=626.635 \mathrm{x}+27.490$ \\
\hline
\end{tabular}


Antioxidant Activity of Ethanol Extract Combinations of Jeruk Purut Leaf (Citrus hystrix Dc.) and Jati Belanda Leaf (Guazuma ulmifolia L.)

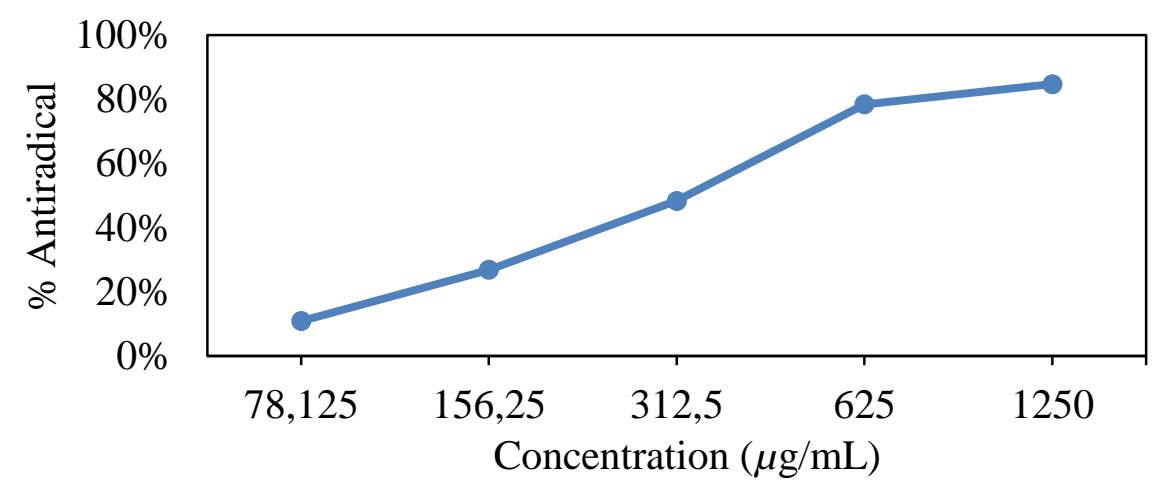

Graphs 1. Correlation of the jeruk purut leaf extract concentration with the $\%$ antiradical

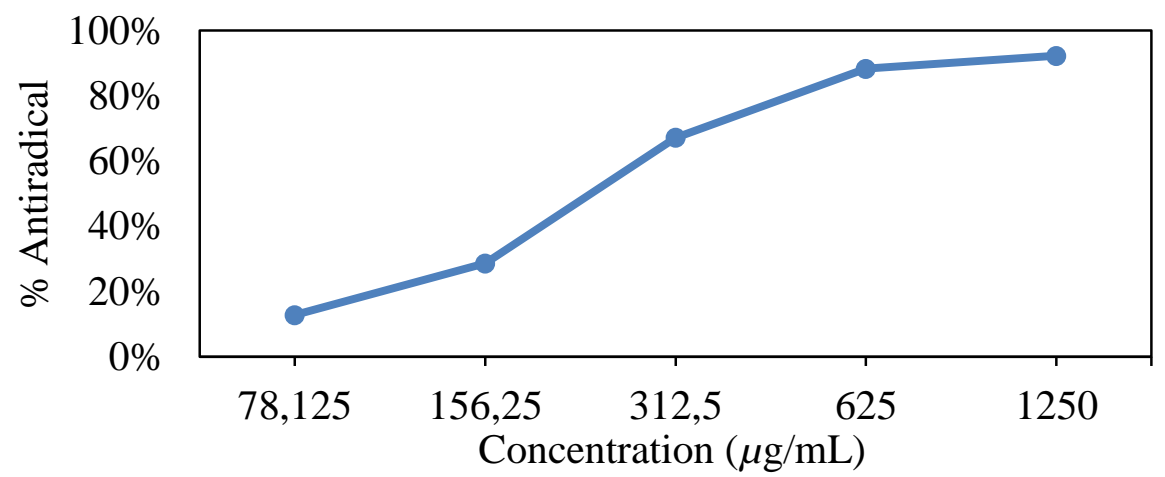

Graphs 2. Correlation of jati belanda leaf extract concentration with the $\%$ antiradical

Table 3. ANOVA test for the extract combinations $\%$ antiradical

\begin{tabular}{lrrcccc}
\hline Source of Variation & \multicolumn{1}{c}{$S S$} & $d f$ & $M S$ & $F$ & $P$-value & $F$ crit \\
\hline Between Groups & 0.247101674 & 2 & 0.123550837 & 0.000704262 & 0.999296028 & 3.885293835 \\
Within Groups & 2105.198057 & 12 & 175.4331714 & & & \\
Total & 2105.445158 & 14 & & & & \\
\hline
\end{tabular}

Table 4. ANOVA test for $\mathrm{IC}_{50}$ of 2 samples and vitamin $\mathrm{E}$

\begin{tabular}{lcrcccc}
\hline Source of Variation & $S S$ & $d f$ & $M S$ & $F$ & P-value & F crit \\
\hline Between Groups & 1364.740017 & 1 & 1364.740017 & 8.174567042 & 0.045970302 & 7.708647422 \\
Within Groups & 667.7980667 & 4 & 166.9495167 & & & \\
Total & 2032.538083 & 5 & & & & \\
\hline
\end{tabular}

Positive controls used were vitamin E. Positive controls were used to compare $\mathrm{IC}_{50}$ or sample inhibitory concentrations of vitamin $\mathrm{E}$ that had high antioxidant activity. Vitamin $\mathrm{E}$ has an $\mathrm{IC}_{50}$ value of $12.59 \mu \mathrm{g} / \mathrm{mL}$ [7]. The data then analysed by anova test, and the result are tabulated in Table 3 and Table 4.
Based on the result of ANOVA test on $\%$ antiradical value of jeruk purut leaf extract and jati belanda leaf extract known $P$-value $>0.05$. There is no average difference in the antiradical percentage value of each combinations ratio.

In anova test $\mathrm{IC}_{50}$ value of 2 samples and vitamin $\mathrm{E}$, it is known that $\mathrm{P}$ - 
value $<0.05$. There is an average difference in $\mathrm{IC}_{50}$ value of both extracts with the standard of vitamin E. Different $\mathrm{IC}_{50}$ values indicate different antioxidant activity. The smaller value of $\mathrm{IC}_{50}$, has the better antioxidant activity.

\section{CONCLUSIONS}

The $\mathrm{IC}_{50}$ values of jeruk purut leaf extracts is $48.70 \mu \mathrm{g} / \mathrm{mL}$, while the jati belanda leaf extracts is $35.92 \mu \mathrm{g} / \mathrm{mL}$.

Based on the results obtained, it is known that the antioxidant activity combination of jeruk purut leaf extract and jati belanda leaf extract is increasing when the amount of jati belanda leaf extract greater. The more the amount of jati belanda leaf extract in combination, it will further suppress the antioxidant activity of lime leaf extract.

\section{ACKNOWLEDGMENT}

We thank to all of laboratory assistants in Faculty of Pharmacy Universitas Muhammadiyah Surakarta for the technical assistant.

\section{REFERENCES}

[1] Robbins, S. L., Kumar, V., Cotran, R. S., 2007. Buku ajar patologi. Jakarta: EGC.

[2] Suryo, 1986. Genetika manusia. Gadjah Mada University Press.

[3] Khaira, K., 2016. Menangkal Radikal Bebas dengan Antioksidan. Sainstek\&58; Jurnal Sains dan Teknologi. 2. 183-187.

[4] Adawiah, A., Sukandar, D., Muawanah, A., 2015. Aktivitas Antioksidan dan Kandungan Komponen Bioaktif Sari Buah Namnam. Jurnal Kimia VALENSI. 1. $130-136$.
[5] Astuti, S., 2012. Isoflavon kedelai dan potensinya sebagai penangkap radikal bebas. Jurnal Teknologi \& Industri Hasil Pertanian. 13.

[6] Rozqie, R., Diah, M., Rukmi, W., 2012. The effect of Jati Belanda (Guazuma ulmifolia Lamk) leaves extract on histopathology of rat's kidney. Tropical Medicine Journal. 2.

[7] Kusumowati, I. T. D., Sujono, T. A., Suhendi, A., Da'i, M., Wirawati, R., 2012. Korelasi kandungan fenolik dan aktivitas antiradikal ekstrak etanol daun empat tanaman obat Indonesia (Piper bettle, Sauropus androgynus, Averrhoa bilimbi, dan Guazuma ulmifolia).

[8] Zuhria, K. H., Danimayostu, A. A., Iswarin, S. J., 2017. Perbandingan Nilai Aktivitas Antioksidan Ekstrak Daun Jeruk Purut (Citrus hystrix) dan Bentuk Liposomnya. Majalah Kesehatan FKUB. 4. 5968.

[9] Kristiana, H. D., Ariviani, S., Khasanah, L. U., 2012. Ekstraksi pigmen antosianin buah senggani (Melastoma malabathricum auct. Non linn) dengan variasi jenis pelarut. Jurnal Teknosains Pangan. 1.

[10] Handayani, H., 2016. Uji Aktivitas Antioksidan Ekstrak Kulit Buah Naga (Hylocereus poyhizus) dengan Metode DPPH (1,1Diphenyl-2Picrylhydrazyl), Karya Tulis Ilmiah, Akademi Farmasi ISFI Banjarmasin, Banjarmasin. 